\title{
China's Dilemmas on the Road to Reforms under Xi Jinping
}

\section{Juhan Värk}

Euroacademy

Mustamäe tee 4,

Tallinn 10621, Estonia

E-mail: juhanvark@hot.ee

Abstract: On 15 November 2012, at the plenary session of the Central Committee of the Communist Party of China, Xi Jinping was elected the Party's general secretary, whereas he also became the chairman of the influential Central Military Commission. Too eager to wait to be inaugurated as President of the People's Republic of China in March 2013, the new national leader announced that in the following decade he is guided by the main objective of his predecessor Hu Jintao to double the prosperity of the people by the year 2020 and to keep the country's economy stable and growing fast. Unfortunately, it will be difficult for the new leader of China to implement his intentions, since, presumably, the country's new leadership will be from the older generation, hardliners, and, most importantly, politically conservative. But the difficulties lie in carrying out economic reforms because of rampant corruption and shadow banking in the central apparatus and in regions.

According to the World Bank's analysis, China has become the world's largest economy. But the large expenditures to military reform and environmental protection are not sufficient for Xi Jinping to accomplish the goal to raise significantly the poor living standards of Chinese people. China has also faced difficulties in complying with the basic principles of its foreign policy, especially after the annexation of Crimea and its incorporation into the Russian Federation by China's strategic partner, Russia. In the past, China has carried out campaigns against "Americanization", although with no tangible results. Thus, the leaders of today's China are faced with a number of dilemmas.

Keywords: army reform, China, corruption, economy reforms, environmental protection, Russia 


\section{Introduction}

On 15 November 2012, at the plenary session of the Central Committee of the Communist Party of China, 59-year-old Xi Jinping was elected the Party's general secretary. Compared to his predecessor, 69-year-old Hu Jintao, a much younger and more energetic leader was now elected to the top post. However, Chinese people do not expect him to carry out radical reforms, because $\mathrm{Xi}$ Jinping has claimed to continue the conservative line of the former PRC Chairman Jiang Zemin. Also, Li Keqiang, Zhang Dejiang, Yu Zhaengsheng, Liu Yunshan, Wang Quishan and Zhang Gaoli, members of the new Standing Committee of the Politburo (the Party's main governing body), are known to be not favouring reforms $(C N N, 2012)$. It is evident that the large-scale economic and military reforms, started by Hu Jintao, will never be abated by his protege Li Keqiang and Xi Jinping himself, who has taken on the US as an economic, cultural and military "challenge". China's new leader declared that his team is fighting for a better life for the people and against corruption. He also promised to ensure gains in China's power and strength. At the same time, Xi Jinping did not mention that the top leadership of Politburo surrounding him is split in their political views. Therefore, it is still too early to expect people to accept the political changes (Ansfield, 2013). However, the article examines the nature of the socio-economic situation in China, and what has Xi Jinping's team done and achieved during the slightly more than a year in his declared main areas of activity. Understanding this may give some idea where China is heading in several dilemma issues under the lead of Xi Jinping.

\section{The splendor and misery of China's economy}

Focusing on the country's main macroeconomic indicators, at first glance it seems that China is a successful leading state among more than two hundred world states. Several economic indicators seem to confirm the same. Today's China has 797.6 million people working, which constitues a huge labor resource. In 2013, China's GDP was 13.39 trillion US dollars and its GDP per capita was 9,800 US dollars. The growth rate of China's GDP was 7.7 per cent in 2012 and 2013, which indicates that China's economy is growing steadily and relatively rapidly. Owing to several economic reforms, carried out since the late 1970s, during which China has moved from a closed centrally planned system to a more market-oriented system, in 2010 China became the world's largest 
exporter. In 2013, China's export capacity was 2.21 trillion US dollars. At the same time the country's import capacity was 1.95 trillion US dollars. This shows that China's foreign trade balance is strongly positive. Although at the end of 2013 China's external debt was 863.2 billion US dollars, at the same time the country's reserves of foreign exchange and gold were altogether 3,821 trillion US dollars (CIA, 2014).

According to information leaked from China's power elite, the Rothschild clan, who recently transformed their headquarters from London to Hong Kong, holds their huge gold reserves in the Central Bank of China. If one were to believe information given in the popular television series Secrets of the World and We have not seen it in our dreams shown on Russian REN-TV channel, both the Rothschilds and China's elite are soon anticipating a new strong world reserve currency known as the "golden yuan". If this intent indeed is realized, the world is faced with a question of what will happen to the US dollar as a world reserve currency and how it will influence the global and US economy. In any case, China under Xi Jinping will no longer accept the leading position of the United States in the global economy. The situation with the US dollar may trigger confusion in Russia's plans to emit a gold-backed common currency in the framework of the Eurasian Union, the Altyn, in 2017. How it will influence China's plans to emit the "golden yuan" is not clear (Ray, 2014). Already in 2013, China stood as the second-largest economy in the world after the US. Taking into account China's past economic dynamics and state resources, the country's leaders and leading economists now argue together that at the end of this year China will pass the United States as the largest economy in the world (The Guardian, 2014). At the same time, many Chinese mass media channels report the state leaders' ambitious economic expansion plans. According to these plans, for example, China wishes to control all major Greek ports and factually already owns Piraeus Port (Rimbert, 2013).

China also wishes to control 90 per cent of all rare earth minerals as components for technology, weapons, etc. (Reuters, 2012). The country's economy has imperceptibly stretched its tentacles into Central and Eastern Europe. For this purpose, in 2011 China founded the forum known as ' $1+16$ ', which includes in addition to China all the Eastern European countries, with the exception of Russia, Belarus, Ukraine, Moldova, and Kosovo. China offers all these countries the total of 10 billion US dollars investment credit. Such assistance is suitable only to those countries of the forum who do not belong to the European Union. To them China can also sell very low-cost low-quality products now filling China's many warehouses. As it is known, according to the EU rules, the Member States are granted each year their main investment finances from the EU structural 
funds and for them exported goods must conform to the euro standards. All this shows that China perceives non-EU states as developing countries, where they can send outdated production (Zuokui, 2013).

At the same time, China is increasingly interested in its economic impact in Africa. It should be recognized that China is Africa's most important single trading partner country, largely due to China's voracious demand for raw material inputs. For the same reason, China runs a huge trade deficit with Africa. As the supply of raw materials varies across countries, China's imports are concentrated in only a few African countries. Last year, South Africa and Angola accounted for nearly 70 per cent of China's imports from Africa. Angola is China's second largest oil supplier after Saudi Arabia. Nearly 45 per cent of Angola's exports go to China. Most Chinese exports to Africa went to wealthier countries such as South Africa (18\% of exports to Africa), Nigeria (13\%) and Egypt (9\%). China's exports to Africa are mainly consumer electronics or investment goods. Last year, the country's exports to Africa amounted to around 90 billion US dollars, making up only four per cent of China's total exports. The value of imports increased last year by less than four per cent, which was clearly lower than in previous years. Among the causes of the slowdown are the drop in world commodity prices and China's slowing economy. China's imports from Africa were down nearly a third in the first quarter of 2014. (BOFIT, 2014)

China's successful export-import policy and large volumes of production have increased the country's financial reserves to such an extent that it attracted US government to sell a huge number of US government bonds to balance the lack of finances for China. Now China is the US largest creditor and in October 2013 had US government bonds holdings amounting to more than 1.3 trillion US dollars (CIA, 2014). However, China is spending large sums on gold purchases. According to the information of the World Gold Council, China bought a record of 1,066 tons of gold last year and with that became the world's largest gold consumer before India (Badkar, 2014).

The above-described China's economic advancements unfortunately show only the country's successes. At the same time, China continues to lose arable land because of erosion and economic development. In great cities, air is heavily polluted. Many water bodies are contaminated. China's shadow banking bubble has burst on the brink. New forms of crime and rampant corruption at all levels are spreading throughout the country. All these negative phenomena hamper China's economic growth and worsen the people's quality of life, which the national leader Xi Jinping with his circle has promised to improve. Speaking of the Chinese economy one should not forget that the country's local municipalities 
have been underfinanced for a long time. The total debt of local municipalities in China currently amounts to 2.7 trillion US dollars (The Economist, 2014).

The following sections discuss the negative phenomena listed above in further detail and the author examines their impact on China's socio-economic environment. The author also takes a look at recent Sino-Russian relations and their impact on China's political-economic position.

\section{China's frustrating environmental situation}

In early April 2014, Chinese Prime Minister Li Keqiang promised to "declare war" on pollution. The country's rapid shift towards industrialization has transformed China's economy, but has also had lasting adverse environmental consequences. China accounts for around half the world's fossil fuel consumption. Last February, a severe winter smog covered nearly 15 per cent of the country and at times even transgressed national borders. Thus, this phenomenon is already developing into an international problem. "We will declare war against pollution and fight it with the same determination we battled poverty," Prime Minister Li Kequiang explained the public government's position in this question.

A related analytical overview, prepared by expert of the Council on Foreign Relations Beina $\mathrm{Xu}$, presents quite a depressing picture of China's environmental situation. It suggests that China's economic rise, which has averaged to around 10 per cent of annual GDP growth in the past decade, has come at the expense of its environment and public health. As the world's largest source of carbon emissions, China is responsible for a third of the planet's greenhouse gas output and has 16 of the world's 20 most polluted cities. Life expectancy in the north has decreased by 5.5 years due to air pollution, and severe water contamination and scarcity have compounded land deterioration problems. According to the World Bank, environmental degradation cost the country roughly nine per cent of its gross national income in 2008 and today it has further increased. China's Ministry of Environmental Protection calculates its own "green GDP" number, estimating the cost of pollution at around 1.5 trillion RMB (yuan), or roughly three to five per cent of GDP, according to its 2010 figures. Data on the public health toll of China's pollution paint a devastating picture. According to a Global Burden of Disease study, air pollution contributed to 1.2 million premature deaths in China in 2010. In late 2013, an 8-year-old girl in Jiangsu province became China's youngest lung cancer patient; doctors attribute her illness to air pollution. (Xu, 2014) 
James R. Gorrie gives even more drastic examples in his book The China Crisis: How China's Economic Collapse Will Lead to a Global Depression (2013), demonstrating that the critically bad environmental situation has created for China negative phenomena and complex problems on social, economic, political and security level and is thus giving several negative warning signals on the global level. For China's foreign policy it is becoming a disturbingly serious factor (Gorrie, 2013).

Sensing the gravity of the situation, Chinese government has suggested numerous solutions for fighting China's notorious air pollution: adding sprinklers on top of skyscrapers, smog-sucking vacuums, air-cleaning bikes. Recently, the Aviation Industry Corporation of China started developing and testing aerial drones that carry air-purifying sprays for use in the most polluted areas (Singh, 2014). Xi Jinping and his government have mapped out ambitious environmental initiatives in recent five-year-plans, although experts say few have been realized. In December 2013, China's National Development and Reform Commission, the country's top economic planning agency, issued its first nationwide blueprint for climate change, outlining an extensive list of objectives to achieve by 2020 . Since January 2014, the central government has required 15,000 factories, including large state-owned enterprises, to publicly report real-time figures on their air emissions and water discharges. And the central government has pledged to spend 275 billion US dollars over the next five years to clean up the air. As it is known, China is also one of the biggest investors in renewables; its spending could total 1.8 trillion RMB (which equals 300 billion US dollars) in the five years through 2015 as part of its promise to cut carbon intensity. According to the National Energy Administration of China, renewable energy sources comprised 57 per cent of newly installed electricity-generating capacity in the first ten months of 2013. Since Chinese authorities have been trying to hide the real situation of the country's environment for years, it is presented by a number of "green protest" organizations. Friends of Nature is one of its oldest, and Global Village and Green Home are among other well-known green protest organizations. Despite state support, these organizations inevitably face constraints deriving from the government's fear that their activities could catalyze democratic social change. Beijing, for instance, has put forward an amendment to China's environmental protection law that would bar such green groups or organizations from suing polluters. The central government has structured its efforts in much the same way that it has pursued economic growth. (Xu, 2014) 


\section{Corruption and crime as slowing development in China}

It is not a secret that China suffers from widespread corruption. In 2013, China was ranked $80^{\text {th }}$ of the 178 countries in Transparency International's Corruption Perceptions Index, on par with Serbia and Trinidad and Tobago, ranking less corrupted than the tied countries Burkina Faso, El Salvador, Jamaica, Panama, and Peru, but more corrupted than Sri Lanka and most developed countries. Like other socialist economies that have gone through monumental transition, such as post-Soviet Eastern Europe and central Asia, post-Mao China has experienced unprecedented levels of corruption, making it one of the major hindrances to the People's Republic of China's social and economic development. (Yan, 2004) China's specialist Minxin Pei (2007) argues that the failure to contain widespread corruption is among the most serious threats to China's future economic and political stability. Corresponding experts in China have estimated that bribery, kickbacks, theft and misspending of public funds costs at least three per cent of GDP.

Coming to power, China's new leader Xi Jinping stressed that one of the Party's most important tasks is to fight against corruption at all levels. This statement made political scientists in China and abroad ask themselves how far Xi dares to go in his fight against corruption. Xi's predecessors were confined to tackle corrupt politicians only on the regional level. But Xi Jinping showed that his words have weight and the fight against corruption has reached the top level. For example, in September 2013, a trial was held in China over high-level party official Bo Xilai, called "the red prince", who for a while had been even seen as Hu Jintao's successor. Unfortunately, Bo Xilai got greedy on his high post and started to demand bribes from everyone who turned to him with request for help. Another high-level official, state homeland security chief and Politburo Standing Committee member Zhou Youngkang proved even more greedy and corrupted. The estimated total value of the illegally acquired movable and immovable property taken from him after the arrest amounted to 14.5 billion US dollars. Among the confiscated property were dozens of bank deposits, a large amount of securities, 300 villas and luxury apartements, 60 luxury cars and a lot of jewels. Along with Zhou Youngkang, nearly 300 of his relatives, friends and colleagues stole large sums of money from the state and the people. All these people have been arrested, but the date of the trial is not yet determined. However, it is clear that this is China's biggest ever corruption scandal. This case also shows that the Chinese leader Xi Jinping is ready to go out to the top level for curbing corruption (Kang \& Blanchard, 2014). According to the information from the news agency Xinhua, the trial over army general Xu Caihou, who is also 
accused of taking bribes from his many subordinates and of misappropriation of state property will start very soon. This case is called the greatest corruption scandal of the China's People's Liberation Army (CPLA). Singapore's leading analyst Richard Jerram thinks that it is not yet clear whether Xi Jinping targets are corruptants or persons unsuitable for him. But a Hong Kong's analyst finds that Xi Jinping punishes only these high-level officials who are hampering his reforms. Both analysts, however, agree in that Xi Jinping treads a risky path. On the one hand, he tries to end corruption among top-level officials, which undermines the legitimacy of the government and the state economy. On the other hand, any penalization of corrupted leading officials would destabilize China's power elite (van der Kamp, 2014).

Corruption in today's China is closely related to new types of crime emerging in the country. One of the best known of these is trafficking of babies. As we know, in 2013 Chinese leadership relaxed the one-child policy in the country and this step dramatically raised the childless couples' demand for babies, and this, in turn, quickly gave rise to a range of corruptive transactions with babies.

\section{China-Russia: factors of the two countries' military-technological convergence}

Chinese strike forces that were formerly, during Hu Jintao's presidency, concentrated along Russian borders are now said to be targeting North Korea. At the same time, China's submarine fleet, most submarines of which have been procured from Russia, are prepared to launch nuclear strikes against major US cities. However, it would be difficult to overestimate the results of the ChineseRussian summit, which began on 24 May 2014 in Shanghai and lasted for a couple days, and during which more than 50 important documents were signed. All of this has created good conditions for the Chinese-Russian militarytechnological convergence. As President Xi Jinping and President Vladimir Putin have repeatedly stressed, the economic convergence of these two major Eurasian countries also gives additional impetus to their cooperation in other fields. This knowledge is very important for Moscow, who is trying to hedge against losses in connection with sanctions imposed by the Western countries due to the Ukrainian-Russian conflict. In doing so, it also tries to take advantage of China, who has now a number of problems in Western countries and is drawn into dispute with several neighboring countries about the ownership of islands in East China Sea and South China Sea. China has set itself a strategic task of 
strengthening the country's defense and systemic army modernization. Although China's military industry has made a qualitative leap in recent years, it cannot yet guarantee the country a full military-technological security in the coming years.

In 2013, China's arms exports comprised approximately six per cent of the world's arms market. As it is known, the second largest on this market is Russia, remaining only behind the two per cent of the US. Thus, the objective prerequisities for the Chinese-Russian military-technical cooperation are met. The intensification of the military-technological cooperation of the two countries has also impacted both international and regional context. According to unofficial information, in 2013 China sourced from Russia weaponry and military equipments in the amount of 1.8 billion US dollars.

Next to the unprecedented gas contract, another important point during the Shanghai summit in May 2014 was the signing of cooperation agreements about using the latest domestic aviation technologies. Shortly before the start of the summit in Shanghai, President Putin informed the Chinese side that under certain circumstances it would be possible for China to produce heavy transport helicopters Mi-26 on its territory, which the Chinese army has great need for. With such a pitch, Russia is ready to give China even greater access to its aircraft industry secrets. But during the Shanghai summit, the Mutual Understanding Memorandum between the United Aircraft Building Corporation and the China's Commercial Aircraft Corporation was signed. The primary objective for them is to design and produce high-capacity, long-range jet planes. A serious problem in Chinese-Russian military-technological cooperation has been the copying of modern Russian military technology, which essentially entails elements of industrial espionage. In this context, China's purchase of 24 Su-30MK2 fighters from Russia in the mid-2000s immediately comes to mind. As a result of this deal, China had a good opportunity to copy and slightly modify the Su-30MK2 fighter into China's J-16 fighter (Baranets, 2012). Thus, the Russian side is reluctant to sell China modern military aircrafts less than 50 aircrafts at a time, as in this case, the great volume of the purchase would compensate possible risks of copying Russian military aircrafts by China.

Beijing has also demonstrated special interest toward Russian marine military equipment. For example, in 2013 a frame contract about the delivery of four diesel-electric submarines Amur-1650 to China was signed. As it is known, China feels the greatest discomfort in certain territorial disputes with Japan, Vietnam and the Philippines over the islands in East China Sea and South China Sea, as well as the continental zones surrounding them. The aforementioned 
countries can count, if necessary, on the support of the US fleets No. 3 or No. 7. However, China can strengthen its influence in the said region only through naval modernization and expansion. China has chosen a special manner to develop its maritime forces - unlike India and many other countries, China is strictly oriented to its production base to manufacture the military aircrafts and vessels it needs. At the same time, China knows perfectly well that without friendly cooperation with foreign, especially Russian, companies, Beijing will not achieve supremacy in these sea areas fast enough. Here the Russian side will provide direct advice and practical assistance to China in the conduct of maritime forces in joint military exercises. The most recent one started on 20 May 2014 and lasted for a week. Signs of increasing trust between Russia and China could already be seen at the beginning of spring last year, when the Russian side implied that they might sell China some S-400 Triumf naval missile systems. It is worth recalling that in 2010, China bought from Russia 15 S-300 missile systems (Agadzhanian, 2014; Keck, 2014b). Russian experts estimate that China's current shipbuilding program is the largest in the world, far surpassing similar programs of the United States and other NATO member states. In Chinese shipyards, tens of multifunctional nuclear and diesel submarines, six mine cruisers, four frigates (all equipped with missile weapons), nine corvettes and an amphibious assault ship are currently being built (Arbatov, 2014). Although such powerful weapons could threaten Russia, leading experts in Russian and Western Chinese affairs find it implausible. For example, on 27 August 2014, BBC quoted an article by an expert of Chinese affairs Roger Boyes of the British newspaper The Times, who said that the Chinese Communist Party needs Russia more than ever and that a series of factors show that the two sides are re-adjusting their strategic positioning (NTD, 2014).

\section{China's national defense and military reform and their first results}

President Xi Jinping, who is head of the leading group for deepening reform on national defense and the armed forces, stressed in the middle of April 2014 that the country's military reform should be guided by the objective of building a strong army. Being also chairman of the Central Military Commission (CMC), Xi Jinping made the remark during the first plenary meeting of the group under the CMC. CMC vice chairmen Fan Changlong and Xu Qiliang serve as the leading group's deputy heads (Keck, 2014a). 
Xi Jinping underlined that "national defense and military reform are an important part and an important symbol of China's overall reform." Stating that the focus is "being able to combat and win battles", Jinping said the reform should target key problems in strengthening combat readiness and weaker links in honing combat effectiveness. He urged to deepen reform to modernize army establishments and said that reform of the commanding system, power structure and related policies should be advanced to support the consolidation of national defense and the building of strong armed forces. An important moment in this logic is the fact that the reform should ensure that the Communist Party of China (CPC) has absolute control over military forces. Chinese president warned, however, that the reform must be carried out in an "active yet prudent" manner. He also underlined that things requiring change must be reformed in a timely, courageous and determined way. "Important reform measures must be taken prudently because a slight move in one part may affect the situation as a whole," Xi Jinping said, adding that repeated reviews and scientific assessment are needed before a move is introduced. Unofficially, Xi Jinping has demanded from army leaders that in some years time China's People's Liberation Army (CPLA) must be ready to attack Taiwan. According to the opinion of military expert Michelle FlorCruzon, CPLA will be capable of full-scale attack on Taiwan by 2020 (FlorCruzon, 2014). The CPC leadership vowed to build modern armed forces with Chinese characteristics as part of a grand reform blueprint, revealed in November 2013 (Xinhua, 2014). Although the national defense and military reform was officially launced in China in early spring 2014 on the highest level, specific preparations for this reform began much earlier. Already in December 2013 the Chinese Ministry of Finance decided that defense budget for 2014 has to be 12.2 per cent higher than the previous year and will amount to 95.9 billion euros. From the beginning of 2013, China's leadership paid much attention to the development and deployment of new weapons, among which cyber weapons occupy an important position. Under strict secrecy, the army leadership recently formed a top secret cyber-espionage unit No. 61398, which is located in a welldefended high-rise building in Shanghai, and which has already carried out several cyber attacks toward the US (Mandiant, 2013).

By speeding up progess with huge resources, China has made significant advances to space, which also promotes a higher level of Chinese missile arsenals, and not only this field. According to Chinese national media, on 14 December 2013, China's unmanned Chang'e-3 spacecraft successfully landed on the Moon. The same day, Yang Yuguang, a leading expert of the China Aerospace Science and Technology Corporation, said: "Soft-landing technology is critical technology necessary for the future manned lunar missions and in the far future we should 
establish lunar bases and utilize resources on the Moon" (Phillips, 2013). Many experts in the world believe that China's space program is primarily about making a political statement about Beijing's growing economic, scientific and geopolitical clout. At the same time, they are convinced that China's space program is closely linked to the country's military industry and is associated with the rearming of the Chinese People's Liberation Army (CPLA). Today CPLA has modern J-108, J-20 and J-31 fighters (the latter a stealth fighter). Unfortunately, the technology of all these fighters has been copied from modern US and Russian fighters. China's super-fashioned X-wing fighter, today still in testing, is promised to be completely original. Alongside the fighters, China's defense industry pays considerable attention to the production of unmanned air vehicles (UAV), the so-called drones. The most popular drones are now the AVIC Sky Eye, an electrically unmanned helicopter, and the TL-8 Sky Dragon for simulating cruise missiles for the Chinese military. Surprisingly, China has used UAVs in the vicinity of the Senkaku Islands on routine missions, much to the displeasure of Japan. A report by the Forecast International said that while the global drone market will rise from 942 million US dollars to 2.3 billion US dollars between 2014 and 2023 due to increasing costs, the Aviation Industry Corporation of China (AVIC) will take over as the world's main drone production company, mostly for Chinese consumers and especially for CPLA (China Defense Industry News, 2014). But as the US administration admits, China is hacking US secrets to develop advanced drones. A closer look at China's other types of armed forces reveals that the navy has now new surface combatants in serial production, new nuclear and diesel-powered submarines, a refurbished aircraft carrier with new ones under construction, amphibious assault ships, and it is expanding its naval infantry. The Second Artillery Corps has a variety of new missiles, including a new road-mobile intercontinental ballistic missile, the DF-41, capable of carrying several nuclear warheads. Added to this are other new capabilities, including advancements in C4ISR support systems, such as new airborne early-warning aircraft, electronic warfare aircraft, additional tankers, new command-and-control systems, UAVs, and space systems that include small satellites and anti-satellite warfare systems. (Minnick, 2014). The above can be shortly summarized with the words of Dean Cheng, China's military specialist at the Heritage Foundation: "So, we see now in China new naval forces, air forces, ground forces and missile forces" (Cheng, 2014).

While the above characterizes the situation of CPLA with its more than two million fighters overwhelmingly positively, foreign military experts also point out that the main weaknesses of the CPLA are widespread corruption of army leadership, long-term lack of combat experience, and lack of hidden resources 
(e.g., secret airfields), and the very time-consuming process of innovation in the CPLA as the world's largest human mass army (inoSMI.Ru, 2014).

\section{Conclusion}

Coming to power, Xi Jinping soon showed strong left-leaning political orientation and that he is more Russian-friendly than his predecessor Hu Jintao, who tried to make friends with the United States and organized military exercises near the Russian border. Hu Jintao was ready, if necessary, to invade Siberia for its natural resources (Värk, 2013). Xi Jinping is trying to achieve success with a close Chinese-Russian economic and military cooperation and has remained flexible in his positions on planning the country's economy. Despite a number of dangerous trends in Chinese economy, such as wide-spread corruption and crime at all levels, swollen shadow banking, huge municipal debts to banks, the credit bubble in a number of economic sectors and the very poor environmental situation, China's new leadership under the lead of Xi Jinping had the courage to launch radical reforms. These important reforms must particularly improve the living standard of ordinary Chinese people and ensure for the country a stable socio-economic situation and normal defense. Also, Chinese society has become more open than it has been in the past. These tasks taken on by Xi Jinping's team are not easy to fulfil. Furthemore, in China's new leader's team, many politicians are hardliners. However, in the society controlled by the reformist Xi Jinping some positive signs can already be noticed. The so-called one-child policy is no longer valid. People can again buy game consoles from stores. Workers incomes have increased so that in large Chinese cities an average worker's monthly salary is up to 650 euros.

What has also changed is the attitude of the Chinese leaders towards environmental protection and corruption. Under Xi Jinping's orders, some high-level state officials and army officers accused of corruption and taking bribes have been arrested. Chinese government has declared war against smog in major cities. Monitoring the purity of water has intensified. China's foreign policy has changed dramatically. The well-known expert of Chinese affairs James Gibney (2014) finds that Xi's China follows Japan's prewar blueprint and now it seems that he is on the right track in this question. While during $\mathrm{Hu}$ Jintao's presidency, China's main enemies were Taiwan, Vietnam, and by all manifestations also Russia, then now the main enemies are the United States, Taiwan, Japan, and Vietnam. At the same time, Russia has become (due to its role 
as China's currently largest supplier of natural gas) a leading economic partner for China. This has made Xi Jinping face a number of dilemmas. On the one hand China recognizes the territorial integrity of all world countries. But when Russia violated this rule in Ukraine, China did not protest against it. Now China accuses Vietnam of some border accidents and the ownership issues of islands located in the East China Sea and South China Sea. Russia, however, refuses to support these China's protests because Vietnam is Russia's important trading and military cooperation partner. It is clear that for China such double play on the part of Russia cannot last forever. For example, Russian-Japanese defense cooperation, started in 2013 on the initiative of Russian Defence Minister Sergei Shoigu, has already created some problems to China. Also, China must quickly find compromises with the US, who is one of China's largest trading partner and also largest finance debtor. Most observers of China believe that Xi Jinping has quickly consolidated political control after his rise to power, yet purge is a sure sign of a leader's weakness, and under Xi Jinping there has been one purge after another, both of civilian leaders and military officers, which is the strongest indication that China's political system is in distress (Chang, 2014). Therefore, China under Xi Jinping stands before great dilemmas and challenges.

Juhan Värk, $\mathrm{PhD}$ is senior lecturer at Euroacademy in Tallinn, Estonia. His fields of interest are economic development problems, EU, Russian and Chinese economics, EU-Russia relations and economic security problems. His latest publication is 'Russia between China and the European Union: Friends or Foes?' in Baltic Journal of European Studies, vol. 3, no. 1(13), pp. 29-43.

\section{References}

Agadzhanian, M. (2014), 'Rossiia-Kitai: voienno-tekhnicheski faktor sblizheniia,' Regnum, 24 May 2014. Retrieved from http://www.regnum.ru/news/polit/1805961. html [accessed Jun 2014]

Ansfield, J. (2013), 'China Takes Aim at Western Ideas,' The New York Times, 20 August 2013. Retrieved from http://www.nytimes.com/2013/08/20/world/asia/ chinas-new-leadership-takes-hard-line-in-secret-memo.html?pagewanted=all [accessed Jun 2014]

Arbatov, A. (2014), 'Aziatsko-Tihookeanskaia strategicheskaia panorama bistro meniaietsa,' Nezavisimaia voiennoe obozrenie, 21 February 2014.

Badkar, M. (2014), "China is Now the World's Largest Consumer of Gold," Business 
Insider, 19 February 2014. Retrieved from http://www.businessinsider.com/chinaworlds-largest-gold-consumer-2014-2 [accessed Mar 2014]

Baranets, V. (2012), 'Kitai sozdal supersamoliet, a dvigateli-to russkiie,' Komsomolskaia Pravda, 2 November 2012. Retrieved from http:/www.kompravda.eu/ daily/25977/2912118/ [accessed Nov 2012]

BOFIT (2014), The Bank of Finland Institute for Economics in Transition Weekly Report on China, Helsinki: BOFIT, 16 May 2014.

Chang, G. G. (2014), "China's Third Era," World Affairs, September/October, pp. $41-48$.

China Defense Industry News (2014), 'China to become biggest drone producer by 2023,' China Defense Mashup, 24 May 2014. Retrieved from http://www.chinadefense-mashup.com/china-to-become-biggest-drone-producer-by-2023.html [accessed May 2014]

Chunquing, X. (2013), 'Australian Media Reveals That Large Numbers of Patients Continue Traveling to China for Organ Transplants,' Human Rights News, 8 November 2013. Retrieved from http://en.minghui.org/html/ articles/2013/11/8/143085p.html [accessed Jun 2014]

CIA (2014), The World Factbook, Washington, DC: CIA. Retrieved from http://www.cia. gov./library/publications/the-world-factbook/geos/ch.html [accessed Mar 2014]

CNN (2012), “China's next leaders: Who's who," CNN International Edition. Retrieved from http://edition.cnn.com/interactive/2012/09/world/china.whos.who/ [accessed Jun 2014]

FlorCruzon, M. (2014), “China’s People's Liberation Army Is Capable of Full-Scale Attack on Taiwan by 2020,' International Business Times, 6 March 2014. Retrieved from http://www.ibtimes.com/chinas-peoples-liberation-army-capable-full-scaleattack-taiwan-2020-1559933 [accessed May 2014]

Gibney, J. (2014), “China Follows Japan's Prewar Blueprint,” Bloomberg View, 18 May 2014. Retrieved from http://www.bloombergview.com/articles/2014-05-18/chinafollows-japan-s-prewar-blueprint [accessed May 2014]

Gorrie, J. R. (2013), The China Crisis: How China's Economic Collapse Will Lead to a Global Depression, New Jersey: Wiley.

InoSMI.ru (2014), 'Kakimi silami na samom dele obladaet Kitai?' Translated from Atlantico, France, 10 March 2014. Retrieved from http://www.inosmi.ru/ world/20140310/218377674.html [accessed Apr 2014]

van der Kamp, J. (2014), 'Xi Jinping may be in over his head with anti-corruption crusade,' South China Morning Post, 8 April 2014. Retrieved from http://www. scmp.com/business/article/1467731/xi-jinping-may-be-over-his-head-anticorruption-crusade?page=all [accessed May, 2014]

Kang, L. \& Blanchard, B. (2014), 'Exclusive: China seizes $\$ 14.5$ billion assets 
from family, associates of ex-security chief: sources,' Reuters, 30 March 2014. Retrieved from http://www.reuters.com/article/2014/03/30/us-china-corruptionzhou-idUSBREA2T02S20140330 [accessed Mar 2014]

Keck, Z. (2014a), 'China Creates New Military Reform Leading Group,' The Diplomat, 21 March 2014. Retrieved from http://www.thediplomat.com/2014/03/Chinacreates-new-military-reform-leading-group/ [accessed Apr 2014]

_ (2014b), 'Putin Approves Sale of S-400 to China,' The Diplomat, 11 April 2014. Retrieved from http:/www.thediplomat.com/2014/04/putin-approves-sale-of-s400-to-china/ [accessed May 2014]

Mandiant (2013), APT1: Exposing One of China's Cyber Espionage Units, Mandiant Intelligence Centre Report, pp. 2-26. Retrieved from http://intelreport.mandiant. com/ [accessed Jun 2014]

Minnick, W. (2014), "China Mixing Military Modernization, 'Tailored Coercion',' Defence News, 13 April 2014. Retrieved from http://www.defensenews. com/article/20140413/DEFREG03/304140016/China-Mixing-MilitaryModernization-Tailored-Coercion- [accessed May 2014]

NTD (2014), “Russian Official Reveals China and Russia’s Delicate Relations,' NTD TV news, 29 August 2014. Retrieved from http://www.ntd.tv/en/programs/newspolitics/china-forbidden-news/20140829/202583-russian-official-reveals-chinaand-russia39s-delicate-relations.html [accessed Nov 2014]

Pei, M. (2007), Corruption Threatens China's Future, Carnegie Endowment for International Peace. Policy Brief No. 55, October 2007, pp. 1-7. Retrieved from http://www.carnegieendowment.org./publications/index.cfm?fa=view\&id=19628 [accessed May 2014]

Phillips, T. (2013), 'Chinese probe lands on the Moon as space programme gathers pace,' The Telegraph, 14 December 2013. Retrieved from http:/www.telegraph. co.uk/news/science/space/10517762/Chinese-probe-lands-on-the-Moon-asspace-programme-gathers-pace.html [accessed Feb 2014]

Ray, L. (2014). 'Global Consequences: Russia Announces Eurasian Union and New Currency Altyn,' Futurist Trendcast, 14 April 2014. Retrieved from https:// futuristrendcast.wordpress.com/2014/04/14/breaking-russia-announces-eurasianunion-and-new-currency-altyn/ [accessed Apr 2014]

Reuters (2012), 'China, a Rare Earth Giant, Set to Start Importing the Elements,' 11 July 2012.

Rimbert, P. (2013), 'China lands in Greece,' Le Monde Diplomatique, English edition, 7 February 2013. Retrieved from http://www.mondediplo.com/2013/02/07piraeus [accessed Apr 2014]

Singh, T. (2014), 'China to Combat Air Pollution with New Smog-Busting Air Drones,' Inhabitat News, 3 May 2014. Retrieved from http:/www.inhabitat.com/china-tocombat-air-pollution-with-new-smog-busting-air-drones/ [accessed May 2014]

The Economist (2014), 'Local government debt: Bridging the fiscal chasm,' 22 February 
2014. Retrieved from http://www.economist.com/news/china/21596991-fancyinfrastructure-one-example-local-government-largesse-which-province-deepestdebt [accessed Apr 2014]

The Guardian (2014), "China's economy over-taking the US does not tell the whole story," The Guardian Economic Blog, 30 April 2014. Retrieved from http://www.theguardian.com/business/economics-blog/2014/apr/30/chinaovertake-us-economy-living-standards [accessed Apr 2014]

Värk, J. (2013), 'Russia between China and the European Union: Friends or Foes?' Baltic Journal of European Studies, vol. 3, no. 1(13), pp. 29-43. http://dx.doi.org/10.2478/bjes-2013-0003

Xinhua (2014), "Xi leads China's military reform, stressing building strong army," Xinhua English News, 15 March 2014. Retrieved from http://www.xinhuanet.com/ english/China/2014-03/15/c_133188420.htm [accessed May 2014]

Xu, B. (2014), “China's Environmental Crisis," Research report, Council on Foreign Relations, 5 February 2014, pp. 1-8. Retrieved from http://www.cfr.org/china/ chinas-environmental-crisis/p12608 [accessed May 2014]

Yan, S. (2004), Corruption and Market in Contemporary China, Ithaca: Cornell University Press.

Zuokui, L. (2013), The Pragmatic Cooperation between China and CEE: Characteristics, Problems and Policy Suggestions, Working Paper Series of Institute of European Studies, Chinese Academy of Social Sciences, vol. 7, no. 6, pp. 1-9. 